\title{
The Presence and Functionality of Comic Latin Sources in Some Letters by Thomas More*
}

\section{Concepción Cabrillana}

University of Santiago de Compostela, Avda. de Castelao, s/n. 15706-Santiago de Compostela, Spain; concepcion.cabrillana@usc.es

For citation: Concepción Cabrillana. The Presence and Functionality of Comic Latin Sources in Some Letters by Thomas More. Philologia Classica 2021, 16 (2), 277-289.

https://doi.org/10.21638/spbu20.2021.209

Detailed examination of the presence and use of Latin comic sources in Thomas More's work has been the subject of little systematic investigation. Among other aspects, the variety of perspectives from which these sources are handled in More's writings, and the diverse functionality that they are endowed with, make this analysis somewhat complex. The object of the article will be restricted to the analysis of some key mentions of Latin comic sources in a particularly significant letter from the point of view of More's defense of humanism, such as the letter to Maarten van Dorp (1515). In addition, the density of allusions to Plautus and Terence is shown in a set of letters and, as a means of possible contrast, in More's epigrammatic texts; an explanatory hypothesis of this presence is also proposed. The analysis contextualizes the place of the letter in which the aforementioned allusions occur, and examines them comparatively. It is suggested that the main functionality of the introduction of references to Latin comedians is to provide eloquent support to establish a significant part of the refutatio of the letter; these references make it possible to shed light on certain inconsistencies in the conduct of the addressee, which weaken the objectivity of his points of view and the correctness of his behavior: hence the Morean criticism of Dorp.

Keywords: Latin comedy, Plautus, Terence, letters, epigrams, Thomas More, Maarten van Dorp, Gerard Geldenhouwer of Nijmegen, humanism, Renaissance.

\section{Introduction. Objectives, justification and structure of the study}

Very little research is currently available on the presence and use of comic Latin sources in the work of Thomas More. ${ }^{1}$ The variety of perspectives from which these

* This study is a revised and enlarged version of the paper presented at the Panel on Thomas More of the II International Conference "From Manuscript to Digital" (University of Jaén, December 1-3, 2020).

1 Excluding the study by Baumann 1984, which was restricted to epigrams and some of More's letters, cf. the opinion of Shoeck 1986, 760; the treatment by Baumann, including what is called Streitschiften ("polemical writings") - which contains a separate section on the letter to Dorp 1984, 110-118, is in

(C) St. Petersburg State University, 2021 
sources are handled in More's writings, and the diverse functionality that they provide, among other issues, make any such analysis somewhat complex. Thus, whereas the initial aims of the present research were more ambitious, the attention required in this first approximation of the topic has obliged me to take a narrower focus here: an analysis of the possible function of the particular mentions that the English humanist makes of Plautus, and a comparison of these with similar mentions of Terence, in the longest of More's letters addressed to Maarten van Dorp in 1515.

The structure of the study is as follows: after a brief section on the fortune of Latin writers of comedy in the period of the texts under scrutiny $(\$ 2)$, we set in context the allusions to be examined ( $\$ 3.1$ ) and then analyze their possible functionality ( $\$ \$ 3.2-3.3)$. A statistical sample of the presence of comic Latin sources in some of More's writings follows, together with a statement that serves to supplement the forgoing observations and at the same time sketch out a direction for future research $(\$ 4)$. Some brief conclusions are then offered $(\$ 5)$.

\section{The fortune of Latin comic authors in the Renaissance}

Part of Greek and Latin dramatic production would crystallize in the Renaissance into what is called Neo-Latin Drama: a transversal, pan-European genre that emerged strongly in Italy around 1300 and in Germany around 1500, and which - after the rediscovery of Plautus and Terence - lasted for several centuries. ${ }^{2}$

The comedies of Plautus, according to Bravo 1993, 76-84, were somewhat relegated to the study of experts for several centuries, until they were performed again in the Renaissance; the existence of the printing press undoubtedly helped to stimulate interest among humanists, so that in the sixteenth century it was not uncommon to study the works of Plautus in universities and to perform some of his comedies on public holidays. This presence in the field of learning, study, and in theatrical performances was even more important in the case of Terence. This author was proposed by Erasmus as a model of Latinity in $1529,{ }^{3}$ but in a letter from 1489 Erasmus himself - who had memorized all of Terence's works in his school years - had already pointed out that his style is wonderfully pure and elegant, and that from this comic author one can learn how to speak authentic Latin better than from any other. ${ }^{4}$ Indeed, Terence occupied a special place in the curriculum of the humanist school. In the words of Bloemendal 2014b, 1185, "the importance of Terence's comedies in the Renaissance can be attested by the professorship in Terence that Frederick the Wise, Duke of Saxony, established at Wittenberg University in the 1530s."

Although the majority opinion is that Plautus' success was at one time much greater than that of Terence - a question I will not go into here - there are those who think ${ }^{5}$ that this opinion should be, at least, very nuanced, something I believe is correct; it is certainly

many cases somewhat generic and is made with a vision more on the lines of the cultural and conceptual background than on a textual basis. A more specific approximation in the case of the Epigrams is proposed in Cabrillana 2021.

2 Cf. Bloemendal 2014a, 473, 476; the chapter in which this statement appears is based, among other studies, on Bloemendal and Ford 2008, Bloemendal and Norland 2013, and Ford and Taylor 2013.

3 Cf. Fontana E. 2008, 124 and below ( $\$ 4)$.

${ }^{4}$ Mack 2014, 56 notes that the comedies of Terence and some Ad familiares letters of Cicero were used in the Renaissance in schools to improve knowledge of Latin syntax and vocabulary.

${ }^{5}$ For example, Parker 1996; Bravo 2001, 88; 90-99. 
a view that is gaining ground in more recent scholarship. In any case, there is very eloquent data regarding the fortune and diffusion of Latin comic production, such as with the Terentian comedy Andria, the first to be performed in the European Renaissance (Florence, 1476) and also the first Latin comedy translated into English (between 1520 and 15306) and performed in Oxford in 1559. ${ }^{7}$ However, the first Latin comedy staged at the court of Henry VIII was Menaechmi by Plautus. ${ }^{8}$ The legacy of the Latin comic authors would be eminently taken up in Italian literary production. ${ }^{9}$

Below $(\$ 4)$ we will return to the question of these two comedy writers' presences, to a greater or lesser extent, in some of More's works.

\section{The letter to Dorp}

\subsection{Context of the allusions}

As we know, the Dutch theologian and humanist Maarten van Dorp (1485-1525), who studied and taught at the University of Louvain, gradually turned to scholastic theology and against humanism. Although he was a friend of Erasmus and More, he had produced some writings with a critical stance on Erasmus' Encomium Moriae and his revision of the Greek text of the New Testament (NT). After an exchange of letters between Dorp and Erasmus which become increasingly critical in tone, More composes a letter to Dorp to convince him of Erasmus' good intentions in the Encomium and in his revision of the NT. More maintains, among other things, the need for and importance of studying the Greek version of the Bible and the Holy Fathers.

With this background, the most direct, broad and particular allusion to the comic Latin sources occurs in More's confirmatio / refutatio within the very careful structure of his letter to Dorp, ${ }^{10}$ in what turns out to be an entertaining defense of the Encomium. Thus, one of the most eloquent of More's themes here is the allusion to an activity in which Dorp himself engaged: writing prologues for Plautus' comedies - Miles Gloriosus and Aulularia - as well as an ending for Aulularia, lost until now. ${ }^{11}$ These supplementary materials produced for Plautus' incomplete works were published some years after Dorp began to call himself theologus. ${ }^{12}$

6 Cf. Twycross 1987.

7 Cf. Brown 2014, 243; 250-251; 253. One of the earliest Italian translations of this same comedy is the Italian version by Machiavelli, probably in 1517; a German translation of all of Terence's works was published in Strasbourg in 1499, and a French one in Paris in 1500-1503 (cf. Lawton 1926; Cupaiuolo 1984, $138 ; 167)$.

8 In Hampton Court, during the month of January 1527: cf. Brown 2014, 255.

9 With regard to Terence - and especially to his Andria and Eunuchus - we can name, for example, Per Paolo Vergerio's Paulus (c. 1390), Leon Battista Alberti's Philodoxus (1426), the seven comedies of Tito Livio dei Frulovisi (1430s), and Giovanni Armonio's Stephaium (c. 1500), a work that also includes Plautine influences; this is also the case with Vincenzo Gabiani’s I Gelosi (1545), Giovan Maria Cecchi's La Moglie (1556), and Antonfrancesco Grazzini's La Spiritata (1561) (cf. Brown 2014, 255-256).

10 Cf. Kinney 1981, 195-196; 1986, xciv-xcvii.

11 These texts are collected in IJsewijn 1981; Dorp's prologue to Miles appears in pp. 106-109, which would correspond to Miles 1-74; the prologue to Aulularia, in pp. 97-98, which would include Aul. 1-74; finally, the complementum to Aul. that corresponds to the vv. 831-1106 can be found in IJsewijn 1981, 98-104.

12 Cf. Kinney 1986, xxii. 
In fact, according to Cooper 1965, 37, the prologue to Aul. was first presented on 3 September $1508^{13}$ and its author began to criticize Erasmus when he was 29 years old, in 1514. On the other hand, Miles was performed in February 1509 by students of the school that William Lily had established, a performance for which Dorp wrote a prologue since it lacked the Plautine original. In the words of Cooper 1965, 37, "Dorp's subsequent fame and influence inspired considerable interest and enthusiasm for Plautine drama and academic production". Schuster's 1962, 17 judgement is very illustrative here: "for his pioneering work on classical productions and dramatic composition as well as for the influence he exerted on later school dramatists, Martin van Dorp of the Lily merits the distinction of being the progenitor of the Louvain academic theatre." ${ }^{4}$

More will appeal very specifically to some consequences of Dorp's own principles of humanism - e. g., his defense of satire and his appreciation of classical poets - to draw him out from his confusion in judging Erasmus: Dorp the humanist cannot continue to be wrong about the style of Erasmus' humanitas. As will be seen, More alludes to this defense of the poets and the power of satire as a stimulus and incentive to self-knowledge: indeed, More would come to say nosce te ipsum to Dorp. In other words, the English humanist highlights what I have called the "inconsistencies" of the humanist Dorp ${ }^{15}$ as a means of making him change his position; ${ }^{16}$ he does so in part by making use of comic Latin sources. Let us now analyze these in some detail.

\subsection{Dorp's first inconsistency}

Although More had already partly defended the Encomium, as requested by Erasmus himself, in the letter to Dorp ( $C W 15,104 / 13 \mathrm{ff}$.) he now returns to this work. Thus, More challenges the words of Dorp, who, at the very beginning of the controversy, has already used the name of a Terentian character to refer to the Encomium in general: that of the servant Davus from Terence's Andria, whose canonical role is that of an entangler in the comedy (cf. vv. 601 and 663-667):

(1) "Ecce repente infausta Moria tamquam Davus interturbat omnia". At quomodo nunc repente? quasi nunc primum Moria repente prodierit, quae iam plus annis septem septies interim novis excusa formis in clarissima luce versata, in omnium sinus recepta sit?

"And now all of a sudden, like Davus, this inopportune Folly is upsetting everything. But in what sense 'now all of a sudden', as if the Folly had just now appeared, when in fact it has been circulating openly for more than seven years, known and cherished by all, going through seven new editions already?" (CW 15, 104/20-25)

13 Dorp was just 23 years old, having been born in 1485 .

14 Apud Cooper 1965, 38.

15 According to Kinney 1986, xxii, and bearing in mind this and other minor publications by Dorp (e. g., the Dialogus in quo Venus et Cupido omnes adhibent versutias (published by Martens in 1914), the Dialogus on the decisions of Hercules, the Oratio de laudibus disciplinarum - that recommends the study of rhetoric and humanistic grammar, as well as theology), it would be wrong to consider Dorp as a firm convert to rigid Scholasticism.

${ }^{16}$ More succeeded, effectively, in persuading Dorp to change his mind, as is attested by the fact that More himself would subsequently write a note to him celebrating the change in his attitude: cf. Sylvester 1977, 464, Heilen 1988, 70. 
On the one hand, More warns of Dorp's lack of objectivity: the success of the Encomium is attested by its wide dissemination over more than seven years. Along with this fact, and somewhat paradoxically, More emphasizes the lasting success of Dorp in the production of Plautine works; ${ }^{17}$ the English author is careful here to make clear that Dorp's dramatic work began seven years ago (with respect to the moment when More's letter was written) and that Dorp is still busy gathering and publishing these texts, something that leaves him little time to mature in the theological field.

On the other hand, More scorns Dorp for criticizing the fact that Erasmus sometimes uses jokes with decorum and less violence than others of whom Dorp himself approves, such as Gerard Geldenhouwer of Nijmegen (ca. 1482-1542). In fact, this humanist monk, who became a Protestant, wrote a collection of satires in 1513 with the eloquent title Gerardi Noviomagi Satyrae octo a Martino Dorpio approbatae. ${ }^{18}$ As Kinney notes 1986, ad loc., these satires, published in Louvain in June 1515, carried a prologue by Dorp dated January 24, 1512, in which Dorp states the following:

(2) Satyrae igitur tuae mihi quidem omni ex parte perplacent.

"Thus these satires of yours please me very much from every point of view." ${ }^{19}$

The manifestation of this position would surely provoke a compromising situation for Dorp, since Gerard attacks both scholastic theologians and corrupt monks and friars with great sarcasm. The double dilemma More opens up for Dorp is clear: (i) why does he admit and praise the work of Gerard and not that of Erasmus, and (ii) why does he criticize a form of working in Erasmus that he himself practiced in his own way at almost the same time. Moreover, More reminds the Dutch humanist of the criticisms he had made in some of his letters, and uses an ironic joke very much in his own style to highlight Dorp's inconsistency:

(3) Sed ita sua cuique blanditur ratio, tam bene suus cuique crepitus olet, ut quum ad aliorum iocos frontem contrahimus, et velut asperos non patimur, nostros neque magis festivos, et magis mordaces amplectamur.

"But so charming does everyone find his own notions, so fragrant does everyone find his own farts, that while we wrinkle our foreheads at other men's jokes and condemn them as bitter we cherish our own even when they are not as amusing and more bitter still" (CW 15, 110/9-12).

This second dilemma reveals the way to analyze another of Dorp's inconsistencies.

\subsection{Dorp's second inconsistency}

More's next reproach of Dorp, which follows the first almost immediately, is for his veiled criticism of the theologians in the prologue that he wrote to the Plautine comedy Miles gloriosus ("The braggart soldier"), ${ }^{20}$ the hilarious work which lacks a known

17 Cf. Cooper 1965, 39.

18 My own typographic highlighting.

19 My own translation of the text that appears in the satires as published by Prinsen (Collectanea van Gerardus Gendelhauer Noviomagus, Amsterdam, 1901, 151-176), p. 151.

${ }^{20}$ More refers to this comedy by using the name of the main character, Pyrgopolinices, a speaking name based on the Greek which can mean "conqueror of cities and towers," although other, somewhat dif- 
prologue. Dorp's prologue respects and imitates well the sharp style of the Latin comedy writer. $^{21}$

The allusion to Plautus' work reminds More of certain words that Dorp has taken from St. Augustine in his Conf. 1. 16. 26, ${ }^{22}$ who in turn takes up a passage from Terence's Eunuchus - to prove that vocabulary can be learned by reading the poets, - a passage alluding to a not very exemplary action of Jupiter with respect to Danaë. ${ }^{23}$ However, More asks Dorp whether he thinks Augustine is advising Christians not to read Terence, a question that would certainly be answered in the negative. ${ }^{24}$ And this, bearing in mind that Terence is far more sparing and less explicit than Plautus when it comes to narrating and describing situations that could be considered immoral. This being the case, More continues on how is it that Dorp has not only written a prologue to Miles Gloriosus but also a prologue and a possible ending to another comedy by Plautus, Aulularia, the last part of which was lost? These compositions by Dorp which, in More's opinion, do not in any way detract from the Plautine original, illustrate well Dorp's taste for Plautus and his work.

To make a clear statement, More quotes a passage (vv. 52-67) from Dorp's prologue to Miles, which shows how the Dutch theologian is capable of attacking and criticizing:

(4) "Primum omnium qui sunt amusi, et litteris Non proletariis male inaugurati, eos Ablegat hinc in maximam malam crucem. ${ }^{25}$ Siquidem stomachabundi oblatratores facere Pergant etiamdum, quod numquam non factitant, Clamoribus ampullosis infremere, et Venena livoris effunditare sui, Et obloqui, et obgannire, et dentibus omnia Arrodere carnivoracibus, et sicut canes Solent, quibuslibet allatrare sibi obviis. Eos homines (siquidem sint et ipsi homines) Quum illitterati sint, quum sint agrarii,

ferent etymologies have been proposed. It has been the figure of this protagonist, rather than the plot of the comedy itself, that has had a notable influence on later literature (cf. Hanson 1965, apud Bravo 1995, 75).

${ }_{21}$ These 122 verses appear for the first time in the edition by Martens (1514), and are also included in Ijsewijn 1981, 106-109.

${ }^{22}$ Cf. also Aug. De civ. D. 2. 7, or Ep. 91. 4. Danaë.

${ }^{23}$ Logically, the original mythological tale contemplates the prodigious union between Zeus and

${ }^{24}$ Although from certain passages by Augustine it could be deduced that the Saint considered the reading of Terence somewhat dangerous for young people, the reality is that Augustine not only knew the Latin comedy writer well, but also held him in high esteem (cf. Aug. Ep. 155. 14). There are also numerous quotes that this author uses from the comic poet (cf. Bravo 2001, 95-96; Fontana E. 2008, 121); and this to such an extent that some quotes from Terence used by Augustine became so integrated in popular culture over the centuries that their first authorship was in many cases not known. An example is Andr. 68: obsequium amicos, ueritas odium parit ("obsequiousness makes friends, the truth just makes you unpopular"). Hieronymus' knowledge and appreciation of Terence was also intense: cf. Bravo 2001, 95-96 and the textual references therein.

25 The expression can be seen in more than one documented passage in Plautus, e. g., Plaut. Cas. 611-612: Ducas easque in maxumam malam crucem / cum hac, cum istac cumque amica etiam tua ("Take her and go and be hanged with my wife, with your own wife, and also with your girl-friend!"; Plaut. Men. 66: abstraxitque hominem in maximam malam crucem ("[the racer] dragged him off to a very sticky end"). Translations of Plautus' comedies are those by W. de Melo 2011a, 2011b. 
Mihi sedulo iussit Plautus hinc abigere.

Sin forte sint praesto, nisi comprimant sibi os, Nihilque graxint, minatus est fore ulmeos, ${ }^{26}$

Vbi hospitio excipientur Acherontico."

"To start with, all of those uncultured louts

Whose erudition ends with uncouth books

Can beat it, Plautus says, and go to hell

Should they, malicious snarlers that they are,

Do any more of what they do continually,

Bellowing out their windy disapproval,

Venting the poison of their chronic envy,

Bad-mouthing, snapping, sinking grisly fangs

In everything, and, just the way that dogs do,

Barking like mad at everyone they meet.

This sort of men (if they are really men,

Illiterates and bumpkins that they are)

Plautus told me to drive away on sight;

Should any stay to hoot and interfere,

He promised them a beating for a greeting

When they become his fellow guests in Hades." (CW 15, 116/6-21)

More insists on Dorp's opinion that there is nothing reprehensible in the satires of Gerard of Nijmegen, and then makes a sort of imitation of the verses quoted from Dorp (CW 15, 118/7-16), where he emphasizes the form of attacking bishops and other religious figures. Against this background, the author of the letter shows his characteristic irony and again turns to classical sources - Hieronymus [Sallust], Tacitus and Epictetus - to appeal to advice that should have led Dorp to be more reasonable; the recourse to Tacitus is especially eloquent, since previously $\left(C W 15,106 / 13-14^{27}\right)$ More has pointed out that Dorp himself has made the Latin historian's advice his own:

(5) Vbi tunc illud Hieronimi, ${ }^{28}$ "Extremae esse dementiae nihil aliud quam odium se fatigando quaerere"? Vbi tunc illud Cornelii Taciti, "Asperae facetiae, quibus multum veri admixtum est, acrem sui memoriam relinquunt"29? Quo tunc fugeret illud Epicteti, "Ne putes omnibus iucunda auditu, quae tibi sunt iucunda dictu"'30?

${ }^{26}$ Cf. Plaut. Asin. 363: mihi tibique interminatust nos futuros ulmeos ("he threatened me and you, saying that we were going to be elmy"; as de Melo 2011a, ad loc. points out, "A joke; since slaves are beaten with elm rods, they can be said to consist of elm wood."

27 ... quum ais, "Asperae facetiae, quibus multum veri admixtum est, acrem sui memoriam relinquunt." (“... when you say, 'Biting quips which contain a large memory behind them.'”); cf. text (5): CW 15, 118/19.

28 Other codices name Sallust instead of Hieronymus, in that the judgement ultimately derives from Sall. Iug. 3. 3, although it also appears in Hieronymus, PL 28. 1403; more specifically, the Salustian text is as follows: Frustra autem niti neque aliud se fatigando nisi odium quaerere extremae dementiae est ("Moreover, to struggle in vain and to gain nothing by wearisome exertion except hatred is the height of insanity", trans. Rolfe).

29 Cf. Tac. Ann. 15. 68. 4.

30 Cf. Epict. Enchiridion 33. 14. 
"What had become of that saying from Jerome, "It is totally insane to work hard just to make people hate you"? What had become of that saying from Cornelius Tacitus, "Biting quips which contain a good deal of truth leave a bitter memory behind them"? What had happened to the one of Epictetus, "Do not suppose everyone will enjoy hearing what you enjoy saying"?" (CW 15 118,18-23)

Finally, Dorp's two inconsistencies are combined: (i) his criticism of those who do not give an example of life, and at the same time, the censure of others - Erasmus - who in fact behave in the same way as he; (ii) his dedication and cultivation of a dramatic production that is less exemplary from the moral point of view (Plautus) than the other (Terence). More thus sentences his reproach to Dorp:

(6) Profecto, mi Dorpi carissime, sic est a natura comparatum, ut modum semper ab aliis exigamus, libertatem omnes indulgeamus nobis.

"Indeed, my dearest Dorp, we are naturally prone to require self-restraint from other people as a matter of course while we give ourselves license to do as we please" ( $C W 15$, 120/1-3).

In short, I believe that the use of classical sources and, in a very particular way, comic sources, allows More to provide an important testimony for the refutatio of the letter and, so to speak, 'to put the finger in the wound' of Dorp's own argument.

\section{Appendix. Plautus vs. Terence?}

At this point, it is necessary to provide more complete data in support of certain criticisms of More's mind and to note at the same time an important point in the piece under consideration. Dorp focused on a line of comic production, that of Plautus, which is lighter in its moral tone than another, Terence. The latter is richer in suggesting, in a more or less veiled way, exemplary behavior within the idiosyncrasies and canons of the comic genre.

This is what More criticizes in Dorp, but how does More himself act in this respect? I will present a mere statistical approximation of the density of use of comic Latin sources in two different genres cultivated by More: epigrammatic poetry and a significant part of his correspondence. ${ }^{31}$ For this statistical approximation to be valid, it must be proportionate or take into account the volume of Plautine production $(16083 \mathrm{vv}$.) - much greater, since 21 comedies have been preserved - and that of Terence ( $4868 \mathrm{vv}$.), from whom we have 6 works. The following Table shows the quantities sorted by genres:

Table. Density of the presence of comic Latin sources in More's Epigr. and correspondence

\begin{tabular}{|c|c|c|c|}
\hline Latin author/Quotes & Epigrams & Letters & TOTAL \\
\hline Plautus (16083 vv.) & $7(0.04 \%)$ & $14(0.08 \%)$ & $21(0.13 \%)$ \\
\hline Terence $(4868$ vv.) & $3(0.06 \%)$ & $17(0.34 \%)$ & $20(0.41 \%)$ \\
\hline
\end{tabular}

${ }^{31}$ I include here the quotations located in the letters to the following addressees: Maarten van Dorp (1515), Peter Giles (1516, 1517), University of Oxford (1518), Germain de Brie (1520), Edward Lee (1520 [two letters]), Francis Cranevelt (1520, 1521, 1522, 1525, 1526, 1528), John Bugenhagen (1526), John Cochlaeus (1529, 1529-1530), Conrad Goclenius (1529) and John Sinapius (1531). These are taken from Cabrillana $(2018,2020)$ and they are listed here chronologically. 
A graphical representation of this data will provide a clearer visualization of the results (Graph).

- Epigrams $\quad$ Letters

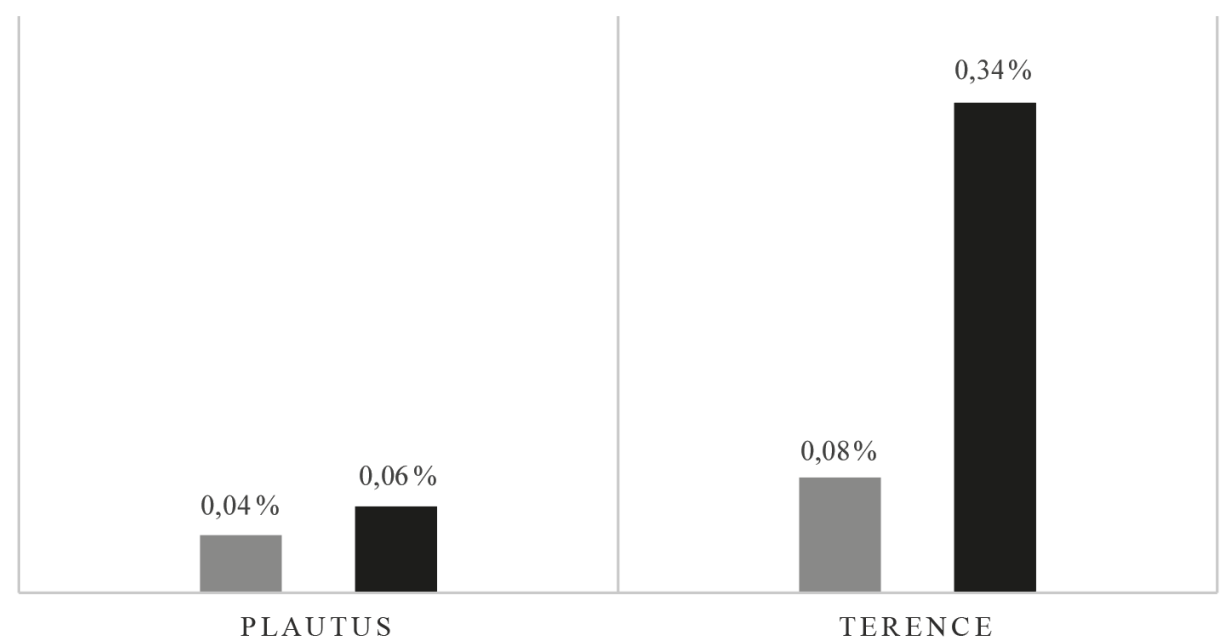

Graph. Percentage density for the presence of comic Latin sources in More's Epigr. and correspondence

The greater presence of Terence is clear, ${ }^{32}$ and it is accentuated to a greater extent in the letters than in the epigrams - a genre that itself tends towards a more pronounced search for the vis comica that can be found more clearly and abundantly in Plautus than in Terence.

Given this data, where should we look for the main reasons underlying this way of working? A connoisseur of Terence - Sophia Papaioannou 2014, 4 - notes that some recent studies include "various critical attitudes towards Terence until the end of the twelfth century - shortly before the rediscovery of Terence as leading force of inspiration behind the Humanist comedies..." (my italics). Recognition of Terence's purus sermo has been quite

32 This greater use can be considered as such if it is assumed (i) that the preserved comedy of Plautus and Terence is taken into account, and (ii) that More knew both Plautine and Terentian comedy. This article assumes both premises, given that what is stated in (i) is the logical and objective way to approach this fact, and that what is stated in (ii) is to be expected if one takes into consideration the enormous presence of classical sources, in general, in More's writing, including classical works that are less well-known than those mentioned here; this last point deserves a more in-depth study, although what has been observed in different works by More already allows us to think in such terms, since the provenance of Plautine quotations by More is of considerable variety (cf., e. g., Cabrillana 2021). However, a possible objection to this statement might be the assumption, for example, that More had read all of Terence's comedies, but only about six of those by Plautus. A brief review of the citations from these two comic authors in the More corpus used for the statistical study in Table 1 reveals that there are allusions to all of Terence's comedies except Heautontimoroumenos; in the case of Plautus, the number of comedies for which references are noted is 17 from the total of Plautus' 21 preserved comedies, namely: Amph., Asin., Aul., Bacch., Capt., Cas., Men., Merc., Mil., Mostell., Per., Poen., Pseud., Rud., Trin., and Truc. On the other hand, it is known that in 1425, Nicholas of Cusa discovered a manuscript containing 16 Plautine comedies, 12 of which had been completely unknown for centuries (cf. Bloemendal 2014, 475). 
widespread among scholars, and admired as well as quoted by great Latin authors such as Cicero $^{33}$ and Horace. ${ }^{34}$ Quintilian places Terence alongside Cicero, Sallust and Vergil as exemplifying correct Latin. ${ }^{35}$

Erasmus had also proposed Terence as a model of Latinity in the educational field. ${ }^{36}$ In addition, we see how Terence consciously chooses to distance himself from the linguistic and literary tradition of Plautus. ${ }^{37}$ It is probably the elegant type of language and the technique used by Terence that has strengthened the notion that he is a good example to follow in learning the Latin language and an influential author, even after many centuries of literary tradition. ${ }^{38}$

But perhaps it is especially the background of Terence's humanitas, in the broad and multi-faceted sense of the term, that has led many authors - and even statesmen such as Benjamin Disraelii ${ }^{39}$ and Winston Churchill ${ }^{40}$ - to make use of passages, motifs and expressions from his works. Certainly, the Latin author does not use the term humanitas specifically, but he does use the term humanus, sometimes in a very dense way: perhaps the most frequently used quote - of Greek descent ${ }^{41}$ - is the famous:

(7) homo sum: humani nil a me alienum puto

"I'm human, and I regard no human business as other people's"42 (Ter. Haut. 77).

This is an expression that has sometimes been understood as a precursor to the Christian humanism that, in my understanding, More sought to practice. Such humanism would still be something like the expression of a model of coexistence destined to improve the relationships that exist between people. Terence tries to put the focus on human beings themselves as individuals with whom to cooperate in the search for the common good: ${ }^{43}$ it is a question, in a way, of seeking a conciliatio hominum. The characters in his comedies

${ }^{33}$ Cf. Bravo 2001, 90; Brown 2014, 243; Manuwald 2014, passim.

34 Cf. Hor. Ep. 2. 1. 182-186.

35 Cf. Manuwald 2014, 185; Papaioannou 2014, 10.

${ }^{36}$ Cf. Fontana E. 2008, 124; van Elk 2013, 413-414. Terence's constant presence as an author studied in schools can also be seen in Bravo 2001, 92-93; 95-96; 99; 101; evidence of this is the fact that he is the Latin author with the most extant manuscripts (more than 650) after Vergil.

37 Cf. Karakasis 2005 apud Papaioannou 2014, 10, on the language of the Eunuchus.

38 Regarding this, and specifically in England, cf. van Elk 2013, 412-413.

39 In his 1837 speech to the House of Commons on the request for Irish elections, which turned out to be a fiasco, Disraeli caused amusement by saying "notwithstanding the amantium ira had resulted, as he

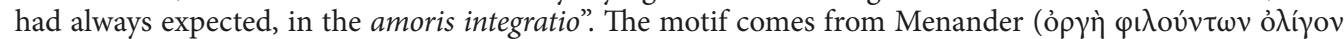

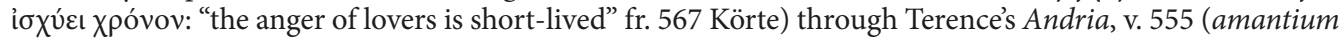
irae amoris integratiost: "lovers' quarrels are love's renewal"), which remained as a proverb: cf. Otto 1890, s.u. amare, 3. The phrase is pronounced in the Terentian comedy after a fictitious quarrel between two lovers (Pamphilus and Glycerium). Disraeli ended his speech by making the assurance that "the time would come when they would hear him"; cf. Brown 2014, 264.

40 The English Prime Minister uses the same Terentian phrase at a time when relations between the United States and England were somewhat strained, as General Eisenhower seemed to be making a series of decisions about the future of Europe without consulting the English nation. Churchill finally thought that the outlook was not as bad as had been feared and sent President Roosevelt a telegram on April 5, 1945 which was intended to improve relations; the telegram ended with the following words: "I regard the matter as closed, and to prove my sincerity I will use one of my very few Latin quotations: Amantium irae amoris integratio est"; cf. Brown 2014, 264.

${ }^{41}$ Cf. Cabrillana 2006, 49.

42 The translations of Terence's texts are taken from those by Barsby 2001a, 2001b.

${ }^{43}$ Cf. Fontana 2008, 56-58. 
follow to a certain extent the canons of the genre, especially the Néa. However, there are certain variations ${ }^{44}$ that in most cases highlight positive characteristics, accentuating the moral value of his comedies, without making this characteristic an absolute. Nevertheless, the introduction of this humanitas will lead Terence to use the technique of contrast between characters to delineate more clearly their characterization, ${ }^{45}$ to express judgements with a moral value, ${ }^{46}$ to strengthen everything that shows a range of feelings typical for a man who views himself positively: an inclination towards forgiveness, ${ }^{47}$ a change of mind when the good of another requires this, ${ }^{48}$ a sensitivity to the misfortunes of others, ${ }^{49}$ understanding, ${ }^{50}$ concern for others, ${ }^{51}$ etc. ${ }^{52}$

In any case, this hypothesis is something that an independent and detailed analysis should be able to confirm, qualify or deny: I leave this line of research open.

\section{Conclusions}

In a very concise way, and in addition to what has been noted throughout the analysis, it can be claimed that, specifically in the passage analyzed, More employs some of the uses of comic Latin sources made by the very addressee of his letter to support one of the pillars of his refutation - pointing out the existence of a series of inconsistencies that weaken the objectivity and correctness of Dorp's behavior in his negative criticism of Erasmus' work. This is not a superficial use, but rather one that belongs to someone who is familiar with the form and substance of classical comic writers. Terence is presented in some ways as a point of introduction and contrast, to focus on Dorp's Plautine appreciation and handling of the material, and from there to More's criticisms.

The question that remains for further investigation is the specific type of use that the English humanist makes of these poets more widely than the context under analysis here; all that we have noted thus far is the greater presence of Terences' work than that of Plautus, as well as a possible general motivation for this.

\section{References}

Barsby J. Terence. Phormio. The Mother-in-Law. The Brothers. Cambridge, (Mass.), Harvard University Press, 2001b.

Barsby J. Terence. The Woman of Andros. The Self-Tormentor. The Eunuch. Cambridge, (Mass.), Harvard University Press, 2001a.

Baumann U. Die Antike in den Epigrammen und Briefen Sir Thomas Mores. Beiträge zur englischen und amerikanischen Literatur, vol. I. Padeborn, Munich, Vienna und Zurich, Ferdinand Schöningh, 1984.

${ }^{44}$ Cf. Cabrillana 2006, 39-52; Fontana 2008, 81-107.

45 Cf. Laches-Phidippus in Hec., Bacchis-Antiphila in Haut., Phaedria-Thraso in Eun., and DemeaMicio and Aeschinus-Ctesipho in Ad.

${ }^{46}$ Cf. the passage of an almost programmatic character of Greek origin: nam id arbitror / adprime in uita esse utile, ut nequid nimis ("I believe that the best principle in life is nothing in excess", Ter. Andr. 60-61), or as said in Andr. 330-331, Haut. 483, Eun. 62-63; 761, Phorm. 241-242, Hec. 380; 608-609; 840, Ad. 605-607, etc.

47 Ter. Ad. $470-471$.

48 Ter. Eun. 154.

49 Ter. Phorm. 91-99.

50 Ter. Hec. 553.

${ }^{51}$ Cf. Callier 1982; Castillo 1986-1987.

52 Cf. Cabrillana 2006, 48-49. 
Bloemendal J. and Ford Ph. (eds). Neo-Latin Drama. Forms, Funcions, Receptions. Hildesheim - Zurich New York, Georg Olms, 2008.

Bloemendal J. and Norland H.B. (eds). Neo-Latin Drama and Theatre in Early Modern Europe. Leiden/ Boston, Brill, 2008.

Bloemendal J. Neo-Latin Drama, in: Ph. Ford (†), J. Bloemendal and Ch. Fantazzi (eds.) Brill's Encyclopaedia of the Neo-Latin World. Leiden/Boston, Brill, 2014a, 473-484.

Bloemendal J. Terence as a School Text: Commentaries, in: Ph. Ford (†), J.Bloemendal and Ch. Fantazzi (eds.) Brill's Encyclopaedia of the Neo-Latin World. Leiden/Boston, Brill, 2014b, 1185-1186.

Bravo J. R. Plauto. Comedias I. Madrid, Cátedra, 1993.

Bravo J. R. Plauto. Comedias II. Madrid, Cátedra, 1995.

Bravo J.R. Terencio. Comedias. Madrid, Cátedra, 2001.

Brown P. Interpretations and Adaptations of Terence's Andria, from the Tenth to the Twentieth Century, in: S. Papaioannou (ed.) Terence and Interpretation. Newcastle upon Tyne, Cambridge Scholars Pulishing, 2014, 241-266.

Cabrillana C. Echoes of Latin Comedy in More's Epigrams, paper to be presented at Thomas More Conference "The Young Thomas More, Life and Writings 1494 - 1522", Dallas, 4-6 November 2021.

Cabrillana C. Terencio. Comedias (Introducción, Traducción y Notas). Madrid, Ediciones Clásicas, 2006.

Cabrillana C. Tomás Moro. Cartas de un humanista (I). Introducción, traducción y notas. Madrid, Rialp, 2018.

Cabrillana C. Tomás Moro. Cartas de un humanista (II). Introducción, traducción y notas. Madrid, Rialp, 2020.

Callier F. A propos des Adelphes de Térence: le personnage d'Hegion et la morale aristocratique. Latomus 1982,41 (3), 517-527.

Castillo C. Caracterización de los personajes y función cómica en el Heautontimoroumenos de Terencio. Cuadernos de Filología Clásica 1986-87, 20, 121-126.

Cooper M.S. More and the Letter to Martin Dorp. Moreana 1965, 6 (2), 37-44.

Cupaiuolo G. Bibliografia Terenziana. Naples, Società editrice Napolitana, 1984.

CW: The Complete Works of Thomas More, vols. 1-15. New Heaven, Yale University Press, 1963-1997.

de Melo W. Plautus. Amphitryon; The Comedy of Asses; The Pot of Gold; The Two Bacchises; The Captives. Cambridge, (Mass.), Harvard University Press, 2011a.

de Melo W. Plautus. The Merchant. The Braggart Soldier. The Ghost. The Persian. Cambridge (Mass.), Harvard University Press, $2011 b$.

Fontana E. g. Terencio. Obras. Madrid, Gredos, 2008.

Ford Ph. J. and Taylor A. (eds.). The Early Modern Cultures of Neo-Latin Drama. Supplementa Humanistica Lovaniensia 32. Leuven, Leuven University Press, 2013.

Hanson J. A. The Glorious Military, in: T. A. Dorey and D. R. Dudley (eds) Roman Drama. London, Routledge \& Keegan Paul, 1965.

Ijsewijn J. Theatrum Belgo-Latinum: Het Neolatijns Toneel in de Nederlanden. Academiae Analecta: Mededelingen van de Koninklijke Academie voor Wetenschappen, Letteren en Schone Kunsten van België, Klasse der Letteren 1981, 43 (1). Available at: https://www.dbnl.org/tekst/ijse001thea01_01/ ijse001thea01_01_0001.php. (accessed:03.2020).

Karakasis E. Terence and the Language of Roman Comedy. Cambridge, CUP, 2005.

Kinney D. Introduction, in: D. Kinney (ed.) The Complete Works of St. Thomas More, vol. 15: In Defense of Humanism: Letters to Dorp, Oxford, Lee, and a Monk. Historia Richardi Tertii. New Haven - London, Yale University Press, 1986, xv-cliv (quoted “CW 15”).

Kinney D. More's Letter to Dorp: Remapping the Trivium. Renaissance Quarterly 1981, 34 (2), 179-210.

Körte A. (ed.) Menander Reliquiae. Leipzig, Teubner, 1957.

Lawton H. M. Contribution à l'histoire de l'humanisme en France: Térence en France au XVIe siécle, éditions et traductions. Paris, Jouve, 1926 [Geneva, Slaktine Reprints, 1970].

Mack P. "Neo-Latin and Reinassance Schools", in: Ph. Ford ( $\dagger$ ), J. Bloemendal and Ch. Fantazzi (eds) Brill's Encyclopaedia of the Neo-Latin World. Leiden/Boston, Brill, 2014, 55-61.

Manuwald G. Cicero, an Interpreter of Terence, in: S. Papaioannou (ed.) Terence and Interpretation. Newcastle upon Tyne, Cambridge Scholars Pulishing, 2014, 179-200.

Martens T. Martini Dorpij sacrae theologiae licentiati Dialogus in quo Venus et Cupido omnes adhibent versutias: ut Herculem animi ancipitem in suam militiam invita virtutem perpellat, Louvain, 1514.

Miller C. H., Bradner L., Lynch Ch. A. and Oliver R. P. (eds) Latin Poems. Vol.3, Part II of The Yale Edition of the Complete Works of St. Thomas More. New Haven, Yale University Press, 1984 (quoted “CW 3"). 
Otto A. Die Sprichwörter und sprichwörtlichen Redensarten der Römer. Leipzig, Teubner, 1964 [1890].

Papaioannou S. (ed.). Terence and Interpretation. Newcastle upon Tyne, Cambridge Scholars Pulishing, 2014.

Parker H.N. Plautus vs. Terence: Audience and Popularity Re-Examined. American Journal of Philology 1996, 117 (4), 585-617.

PL: Patrologiae cursus completus: Omnium SS. Patrum, Doctorum Scriptorumque Ecclesiasticorum sive latinorum, sive graecorum, accurante J. P. Migne. Turnhout, Brepols, 1956-1988.

Rolfe R. C. Sallust. The war with Catiline. The war with Jugurtha. Cambridge (Mass.), Harvard University Press, 2013.

Schoeck R.J. Rec. U.Baumann, Die Antike in den Epigrammen und Briefen Sir Thomas Mores, Beiträge zur englischen und amerikanischen Literatur, vol. I, Padeborn, Munich, Vienna und Zurich, Ferdinand Schöningh, 1984. Renaissance Quarterly 1986, 39/4, 760-762.

Schuster L. A. "Henry VIII", A Neolatin Drama by Nicholas Vernulaeus, trans. and edited with a History of the Louvain Academic Theater. Austin, Texas, University of Texas Press, 1962.

Sylvester R.S. Thomas More: Humanist in Action, in: R. S. Sylvester and G. Marc'hadour (eds.) Essential Articles for the study of Thomas More. Hamde-Connecticut, Archon Books, 1977, 462-469.

Twycross M. Terence in English: an Early Sixteenth-Century Translation of the 'Andria' (Medieval English Theatre Modern Spelling Text (6). Lancaster, University of Lancaster, Department of English Language and Medieval Literature, 1987.

van Elk M. 'Thou shalt pesent me as an eunuch to him': Terence in Early Modern England, in: A. Augustakis and A. Traill (eds) A Companion to Terence. Chichester, UK, Wiley-Blackwell, 2013, 410-428.

Received: June 4, 2021

Accepted: September 2, 2021 